\title{
THE HOLY BLESSED PRINCE LAZARUS OF SERBIA WHO DIED IN THE BATTLE WITH THE TURKS ON THE KOSOVO FIELD ${ }^{1}$
}

\section{Abstract:}

The article is dedicated to Prince Lazarus (c. 1320-89), who ruled Serbia in the14th century for about two decades and died in the battle with the Turks on the Kosovo field in 1389 . He proved to be a successful ruler and diplomat, managing to unite a large part of the scattered Serbian lands and strengthening dynastic ties with his Balkan neighbors, as well as resolving the conflict of the Serbian Church with the Constantinople Patriarchate. Almost immediately after his death, Prince Lazarus was proclaimed a holy martyr. He occupies a prominent place in Serbian literature and folklore. In the 16th century the cult of Prince Lazarus spread to the Moscow state, but was less important than the veneration in Russian lands of St Sava of Serbia and St Simeon of Serbia.

\section{Keywords:}

Serbia, Prince Lazarus, death in battle with the Turks, canonization, reflection of his figure in Serbian literature and folklore, his cult in the Russian lands.

АННОТАЦИЯ: И.И. КАЛИГАНОВ. «СВЯТОЙ БЛАГОВЕРНЫЙ КНЯЗЬ ЛАЗАРЬ СЕРБСКИЙ, ПОГИБШИЙ В БИТВЕ С ТУРКАМИ НА КОСОВОМ ПОЛЕ».

Статья посвящена князю Лазарю, правившему Сербией в XIV в. около двух десятков лет и погибшему затем в битве с турками на Косовом поле в 1389 г. Он проявил себя успешным правителем и дипломатом, сумел объединить значительную часть разрозненных сербских земель, укрепить династические связи со своими балканскими соседями, урегулировать конфликт Сербской церкви с Константинопольской патриархией. Почти сразу же после гибели князь Лазарь был провозглашен святым мучеником. Его фигура заняла видное место в сербской литературе и фольклоре. Культ князя Лазаря в XVI в. проник в Московское государство, но был меньшим по сравнению с почитанием в русских землях св. архиепископа Саввы Сербского и св. Симеона Сербского.

\section{Ключевые слова:}

Сербия, князь Лазарь, гибель в битве с турками, канонизация, отражение его фигуры в сербской литературе и фольклоре, его культ в русских землях.

$\mathcal{S}$ Prince Lazarus, a ruler of Serbia, unifier of the Serbian lands, builder folklore as one of the main heroes of the battle against the Turks on the Kosovo field in 1389. After his death he was immediately canonized as a holy martyr by the Serbian Orthodox Church.

\footnotetext{
1 The work was carried out with the financial support of the RFBR (grant № 18-512-76004).
} 
Prince Lazarus Hrebelyanovich's rule of Serbia did not begin at an auspicious time. The country was torn apart by strife between large feudal lords, and a part of the territory of the former Serbian state was occupied by warlike neighbors. From the south, the Turks pressed into the northern Balkans, and in 1371 they defeated the Serbs on the Maritsa river. Almost simultaneously, the line of the Nemaniches dynasty, which had ruled Serbia for more than two hundred years, was interrupted. Its last representative, Tsar Stefan Urosh, died, leaving no heirs. The court aristocrat Lazarus, son of the tsar's logothete (head of the office) named Pribats, who owned the town of Prilepets on the South Morava river, was among the contenders for the throne and came out on top. His marriage to Militsa, an aristocrat who was distantly related to the reigning Nemaniches dynas-

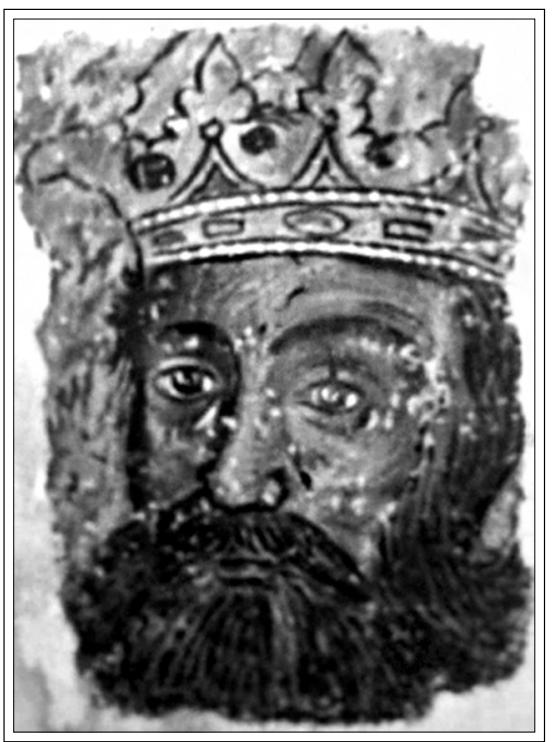

Prince Lazarus,

the lifetime fresco at the monastery of the Ascension. Ravanitsa,

$1385-87$ ty, greatly contributed to strengthening his power. Lazarus proved to be a successful ruler and diplomat. He enhanced military and political ties with his neighbors by marrying his daughters to Vuk Brankovich, the ruler of the Kosovo region and northern Macedonia; to Alexander - the son of Ivan Shishman, the Bulgarian tsar from Tarnovo; and to Djuradzh Balshich, the Serbian ruler of northern Albania. Additionally, he managed to resolve the long-standing conflict between the Serbian Orthodox Church and the Patriarchate of Constantinople in relation to the Serbs' unauthorized installation of their own patriarch in 1345 without reaching an agreement on the legitimacy of such an important church legal act.

Having expanded the territorial boundaries of his possessions, Lazarus did not aspire to the status of a tsar or king but was content with the title of prince. Therefore, scholars later began to call the years he reigned the Serbian lands belonging to him "knyazhevina" / "the period of the prince's reign." In addition to politically strengthening the country, Prince Lazarus significantly improved its economic condition and embarked on creative activities. In the capital of the principality of Krushevats, the magnificent church of the Proto-Martyr Stephen ("Lazaritsa") was erected at his order; he founded his future tomb - "zaduzhbina" Ravanitsa (a fortress monastery with powerful walls and towers); and built the monastery of the Blessed Virgin Mary in Veludzhe. These temples had specific features, which later became marks of the Moravian school in Serbian architecture. Their walls were made by alternating layers of ashlar limestone with 
three rows of bricks and had decorative blind arches; cruciform roofs were covered with lead or tile; the drums of the domes were high and narrow; and the main room had side conches-chapels. Prince Lazarus was also a generous donator to a number of Athos monasteries, including the Serbian Hilandar, Russian St Panteleimon and the Greek Lavra of St Athanasius. Many writers and scholars who had left their homes due to the Turks' military expansion in the Balkans found shelter at Prince Lazar's court in Krushevats.

The Turkish conquest of the Balkan lands was carried out sequentially and methodically. Victories and defeats of the Turks alternated repeatedly. The most famous of the Serbs' battles with the Turks was the battle on the Kosovo field, which took place on 15 June 1389, on the day of St Vit (in Serb. - "Vidovdan"). This battle resounded deeply in Serbian folk memory and was embodied in monuments of Serbian literature and folklore. Prince Lazarus led the combined forces of the Balkan peoples (Serbs, Bosnians, Croats, Hungarians, Walachians and Albanians), totaling about $12-20$ thousand people. They were met by the Turkish army under the command of Sultan Murad, who outnumbered them by a factor of 1.5 . The bloody battle lasted all day with varying success for both sides. The well-known confusion in the Turkish camp came after the unexpected death of Sultan Murad. The Serbian knight Milosh Obilich came to his headquarters on the pretext of delivering an important message and, when he was brought to Murad, immediately removed a dagger from the folds of his clothes and stabbed the sultan in front of his bodyguards and courtiers. The Turks tore the offender to pieces, but they were stunned by what had happened. Bayezid, the sultan's son, took advantage of this critical situation: he ordered that his brother and rival, Jakub, be strangled, and then he led the Turks in a fierce attack on the Serbs. The wounded Prince Lazarus was captured and taken to the tent of Murad and was beheaded over his body. The Turks were victorious, but they them-

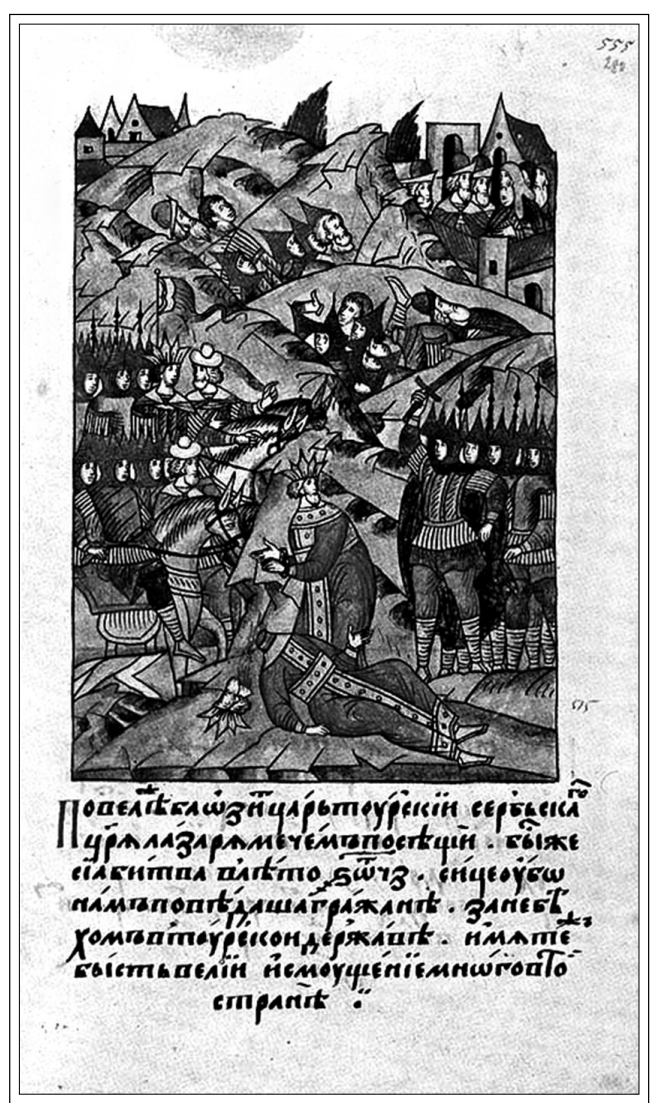

Miniature depicting the death of Prince Lazarus on the Kosovo field, the illuminated compiled Chronicle, second Osterman volume, mid-16th century 
selves suffered heavy losses, and their pressure on the northern Balkans was relatively reduced. Serbia became the vassal of the Turks but was able to defend its partial freedom for another 70 years.

Relatives bought back the body of Prince Lazarus, and a few years later it was buried in the princely tomb in Ravanitsa. Lazarus, who had been executed by the Turks, was proclaimed a great holy martyr by the church: an Orthodox believer who had accepted death for Christ at the hands of the gentiles. In honor of the supreme ruler who became a sufferer of Christ, over two dozen works in Serbian literature were created over the course of half a century: lengthy and short hagiographies, laudatory words, services, canons, troparia and stichera. Some of them were very unusual in the nature of the material on which they were created. For example, Helena (in the monastic order of Euthymia), the widow of the despot John Uglesha, who died in 1371 on the Maritsa river, embroidered with gold and silver thread a text of praise to Prince Lazarus on the cover of the holy shrine. And the son of the Prince, the despot Stefan Lazarevich, was allegedly the author of the poetic epitaph to his father on the marble pillar installed on the Kosovo field. The rest of the works were quite traditional (texts written on parchment and paper) and belonged to famous or anonymous medieval authors. Among the former were the Serbian Patriarch Daniel III, who composed an eulogy to Prince Lazarus in the last decade of the fourteenth century, and the Greek Anthony Raphael Epaktit, who wrote a work about the sufferer of a similar genre.

Other hagiographic and hymnographic works of the period dedicated to Prince Lazarus are anonymous. These include a short life with a verse accompanying the text of the service, the Life of Prince Lazarus, The Word and, in part, memory from the life, Life and authority, placed in the so-called Pech Chronicle. Anonymous church chants dedicated to St Lazarus were also quite numerous. The first of these that should be noted, is the stichera and troparia to Lazarus, composed to glorify the saint on the occasion of bringing his relics to Ravanitsa. Apparently, in the same monastery at the beginning of the 15th century, a service was also written for the great martyr with two canons, the first of which contains an acrostic "Praise Lazarus, my God, grant me reason." Starting from the second half of the 15th century there was a break of about a century and a half in the development of the cult of St Lazarus - only in the last decade of the 17th century did the famous manuscript copyist, hieromonk Cyprian from the monastery of Racha, create a new stichera dedicated to Prince Lazarus. The weakening of the tradition of church veneration of this saint was partly offset by the Serbian oral folk tradition. It became especially widespread after the "Great Migration of the Serbs" to the Austrian possessions in 1690. Prince Lazarus becomes one of the main characters of the Kosovo folklore cycle, in which the story with the martyr's truncated head is often played out. Starting from the 18th century, folklore trends became noticeable in Serbian literature, as evidenced by the Parable of the Kosovo battle, the Tronosh genealogy and, in part, the Slavo-Serbian Chronicles by Georgy Brankovich (end of the 17th to the beginning of the 18th century). 
Information about the battle of Kosovo and the death of Prince Lazarus reached Russia by the end of the 14th century, but any Serbian written documents about the saint were long unknown to the Russian people. Indirect information about what happened penetrated Russia mainly through the story of the battle of Kosovo and the death of Prince Lazarus, which was read in the biography of his son, Stefan Lazarevich, compiled by the Bulgarian writer Constantine of Kostenets. It began to spread in the northeastern Russian lands from the first decade of the 16th century, and the Kosovo story made it into all of the editions of the Russian Chronograph of the 16th-17th centuries, beginning with the first of them compiled by hieromonk Dositheos (Toporkov) between 1516 and 1522 . Later this story was included in the Nikon Chronicle. In the middle of the 16th century the Hilandar abbot Paisius, along with other gifts, brought the icon and service to Prince Lazarus of Serbia for Ivan the Terrible to Moscow. Apparently, from this time on, the service to this Serbian martyr began to spread in the Russian manuscript tradition, but it is still poorly studied. At least two Russian copies of the service to Prince Lazarus of Serbia dating from the end of the 16th century are known. These were in service minaions located in Ust'-Orel and Sol'vychegodsk - the Siberian estates of the Russian industrialist Nikita Stroganov. In the 1580s Russian singers sang and provided musical notation to individual stichera to Prince Lazarus. An example of this are materials from the cantatory collection of the Kirillo-Belozersk Monastery dated "no later than 1586."

The oldest Russian image of Prince Lazarus in Muscovite Russia is considered to be one of the murals from 1564 of the Archangel Cathedral in the Moscow Kremlin, which is the burial site of the Russian grand princes and tsars up to Peter I. Prince Lazarus was painted here along with other Serbian ascetics - Saints Simeon and Sava, whose cult had penetrated the Russian lands much earlier. In general, we can note a weaker spread of veneration of Prince Lazarus in Russia in comparison with the other famous South Slavic ascetics: Ivan of Rila, Sava and Simeon of Serbia. However, to explain it by the late contacts between Moscow and Ravanitsa monastery (where the relics of the martyr were stored and whose monks first arrived to the Russian capital only in 1693) would be a mistake. After all, the cult of the Serbian martyr had reached Moscow through Athos a century and a half earlier. Most likely, the reason should be sought in the conceptual and political considerations of the Moscow state. St Lazarus became a prominent cult figure among the Serbs as the first supreme ruler of an Orthodox country to fall in battle against the Mohammedans. However, he was not able to become a figure of such significance for veneration among Russians - inhabitants of an Orthodox state - whose leaders were preparing for a decisive struggle against Kazan, Astrakhan and the Crimea, and who had developed the idea of Moscow as the Third Rome. This would be suggesting the possibility of defeat in Russian army's conflict and the death of the first legitimate Russian autocrat, Ivan the Terrible, who had just been crowned Tsar, or those who stood behind him at the head of Russia. Additionally, there were no grounds for ranking Prince Lazarus as 
a great martyr, as he is called in one of the first Serbian hagiographies dedicated to him. The prince did not undergo a string of terrible tortures in the name of Christ, and he did not face the alternative of changing his faith in order to save his own life - his execution was almost instantaneous and was caused by the Turk's desire for revenge for the death of Sultan Murad. This is perhaps the reason why, in subsequent Serbian hagiographies and later Russian written sources, he began to appear as the "Blessed" or "Faithful" St Prince Lazarus of Serbia.

Translated by the author

\section{BIBLIOGRAPHY}

Alekseev S.V. Pamiatniki serbskoi srednevekovoi agiografii XIV-XVII vv. Perevody $\mathrm{i}$ issledovaniia. Sankt-Peterburg, 2017. T. 2. Zhitiia XIV-XVII vv. Rodoslovy. Letopisi. $462 \mathrm{~s}$.

Trifunović Đ. Srpski srednjovekovni spisi o knezi Lazaru i Kosovskom boju. Kruševac: Bagdala, 1978.

\section{ILLUSTRATIONS}

1. Monastery of the Ascension of Christ, Ravanitsa, 1375-77.

2. The Krushevats fortress.

3. Cathedral of the Proto-Martyr Stephen (Lazaritsa), Krushevats, 1377-80.

4. Prince Lazarus, the lifetime fresco at the monastery of the Ascension, Ravanitsa, 1385-87.

5. Gazimestan Memorial monument on the Kosovo field.

6. Praise to Prince Lazarus. Embroidering of the nun Euphemia.1402.

7. Sts Prince Lazarus and Princess Militsa. The fresco at the monastery of the Assumption in Lyubotitse. About 1403.

8. Miniature depicting the death of Prince Lazarus on the Kosovo field, the illuminated compiled Chronicle, second Osterman volume, mid-16th century.

9. Fresco of Prince Lazarus on the pillar of the Kremlin Archangel Cathedral, 1564 under the painting of the 17 th century.

10. Holy Great martyrs Prince Lazarus and George the New. Icon of the Hilandar monastery, the middle of the 16th century. 